\title{
The heat shock protein 70 gene as a new alternative molecular marker for the taxonomic identification of Streptomyces strains
}

Yang $\mathrm{Hu}^{1 \dagger}$, Fengxian Sun ${ }^{2+}$ and Weiying $\mathrm{Liu}^{1 *}$ (1)

\begin{abstract}
With the developments in taxonomy, the classically used highly conserved 165 rRNA molecular marker has shown some disadvantages among closely related species. For further taxonomic studies of the prokaryotes, specific PCR primers were designed from two conserved regions in the amino acid sequences of the 70-kDa heat shock protein sourced from 20 different genera in actinomycetes. These were used for the amplification of the hsp70 genes in 16 Streptomyces strains. Then, we investigated the phylogenetic relationships among these Streptomyces strains and compared the tree topology based on the hsp70 gene with those based on the previously used markers (16S rRNA and gyrB). To our knowledge, this is the first use of the $h s p 70$ gene as a molecular marker for the taxonomic identification of Streptomyces.
\end{abstract}

Keywords: $16 \mathrm{~S}$ rRNA, Molecular marker, hsp70, gyrB, Taxonomic identification

\section{Introduction}

The highly conserved 16S rRNA gene, also known as the 'bacterial fossil', encodes small subunit of the ribosomal RNA (rRNA) in prokaryotes. It contains 10 variable regions and 11 constant regions (Woese et al. 1975). Phylogenetic analysis based on the 16S rRNA gene is considered to be a simple and appropriate tool for the construction of bacterial phylogenetic relationships. Thus, it is one of the most commonly used methods for identifying microorganisms (Amann et al. 1995; Stackebrandt and Goebel 1994; Woese et al. 1990). Recently, molecular techniques based on the PCR, such as DGGE, LH-PCR, cPCR, SSCP, ARDRA, AFLP, RFLP, FISH and T-RFLP, have provided outstanding tools for the detection, identification, and characterisation of microorganisms based on this gene region (Giraffa and Neviani 2001). However, the high percentage of sequence similarity among closely related species limits its effectiveness

*Correspondence: liuweiying3@126.com

${ }^{\dagger}$ Yang Hu and Fengxian Sun contributed equally to this work

${ }^{1}$ Department of Pathogen Biology, School of Basic Medical Sciences,

Tianjin Medical University, 22 Qi-Xiang-Tai Road, Tianjin 300070, China

Full list of author information is available at the end of the article
(Ash et al. 1991; Christensen et al. 1998; Yamamoto and Harayama 1998).

Consequently, other protein-encoding gene sequences have been evaluated for use as tools in phylogenetic and taxonomic identification (Küpfer et al. 2006). The gap and ompA genes, which encode glyceraldehyde-3-phosphate dehydrogenase and outer-membrane protein $3 \mathrm{~A}$ respectively, were used to identify five species of Escherichia, but these did not form a monophyletic group (Lawrence et al. 1991). In addition, the sequences of recA, rpoB, inf $\mathrm{B}, f u s \mathrm{~A}$ and nifD, which are involved in DNA recombination or DNA repair, the RNA polymerase $\beta$-subunit and translation initiation factor 2 , the protein synthesis elongation factor- $G$ and the $\alpha$ subunit of the dinitrogenase protein were also used to describe the phylogenetic relationships of different bacterial genera (Das et al. 2014; Hedegaard et al. 1999; Holmes et al. 2004; Lloyd and Sharp 1993; Mollet et al. 1997). Unfortunately, despite having a higher phylogenetic resolution than the 16S rRNA sequences (Yamamoto and Harayama 1996), some of the phylogenetic trees did not form distinct phylogenetic groups (Dauga 2002). Recently, the gyrB gene, which encodes the subunit B protein of DNA gyrase, was proposed as a suitable phylogenetic marker. It was most 
commonly used in the identification and classification of the evolutionary relationships of closely related species, due to its success (Kasai et al. 2000; Venkateswaran et al. 1998; Yamada et al. 1999; Yamamoto et al. 1999; Yamamoto and Harayama 1998).

Heat shock proteins (HSPs) are groups of stressresponse proteins that have been demonstrated to be universally distributed across biological groups from bacterial to human beings (Hunt and Morimoto 1985). According to their biological activities and apparent molecular weights, HSPs are classified into four major families: $h s p 90, h s p 70, h s p 60$, and small HSPs including $h s p 27$. A study previously revealed that human $h s p 70$ is $73 \%$ identical to Drosophila hsp 70 and is $47 \%$ identical to Escherichia coli DnaK. These have been considered as useful phylogenetic markers (Hunt and Morimoto 1985). We aimed to develop a set of novel PCR primers that allow for the amplification of the $h s p 70$ gene. These were then used to study the phylogenetic relationships among Streptomyces strains.

\section{Materials and methods}

\section{Strains and culture conditions}

All the Streptomyces strains used in this study were collected in our laboratory. E. coli strains were typically cultured in Luria-Bertani (LB) medium or on LB agar plates at $37^{\circ} \mathrm{C}$ (Sambrook and Russell 2001). Where appropriate, the media contained the antibiotic ampicillin $(1 \mu \mathrm{g} /$ $\mathrm{mL}$ ). To prepare the total genomic DNA of Streptomyces, Tryptone Soy Broth liquid medium containing $0.5 \%$ glycine was used for culturing the strains (Hopwood et al. 1985).

\section{Chemicals and reagents}

All the chemicals and reagents used were of the highest purity commercially available. Taq polymerase was purchased from TaKaRa Bio Inc. (Japan).

\section{Preparation of genomic DNA}

All bacteria genomic DNA was isolated using the method described by Hopwood (Hopwood et al. 1985).

\section{PCR amplification of target genes}

PCR amplification was performed using an Eppendorf Personal Master Cycler. A master mix of $50 \mu \mathrm{L}$ used for the PCR reaction contained: $5.0 \mu \mathrm{L} 10 \mathrm{X}$ PCR Buffer, $3.0 \mu \mathrm{L} \mathrm{MgCl}_{2}(25 \mathrm{mM}), 4.0 \mu \mathrm{L}$ dNTPs $(2.5 \mathrm{mM}$ each), $1.0 \mu \mathrm{L}$ of degenerate PCR primers (20 mM each), $2.5 \mu \mathrm{L}$ dimethyl sulfoxide, $1.0 \mu \mathrm{L}$ genomic DNA (ca.0.2 $\mu \mathrm{g}$ ) and $0.5 \mu \mathrm{L}$ Taq polymerase. The amplification conditions were as follows: (a) 1 cycle for $3 \mathrm{~min}$ at $94{ }^{\circ} \mathrm{C}$; (b) $94{ }^{\circ} \mathrm{C}$ for $1 \mathrm{~min}, 64{ }^{\circ} \mathrm{C}$ for $1 \mathrm{~min}$, then $72{ }^{\circ} \mathrm{C}$ for $1.5 \mathrm{~min}$ for 35 cycles; (c) 1 cycle at $72{ }^{\circ} \mathrm{C}$ for $10 \mathrm{~min}$.
In addition, the $16 \mathrm{~S}$ rRNA gene and the gyrB gene were amplified by PCR using the primers as described previously (Calcutt 1994; Edwards et al. 1989). The PCR products were directly sequenced by an ABI Genetic Analyzer 3730 (Invitrogen Bio Inc., Shanghai, China) which used the $16 \mathrm{~S}$ rRNA primers and F-1S (5'-GAGGTCGTGCTG ACCGTGCTGCA-3')/F-2R (5'-GTTGAT GTGCTG GCCGTCGACGT-3') for gyrB (Hatano et al. 2003).

\section{Gel analysis and DNA sequencing}

All PCR products were analyzed using $1.0 \%$ agarose-gel electrophoresis, stained with ethidium bromide (AMRESCO, USA). PCR products were directly sequenced by ABI Genetic Analyzer 3730 (Invitrogen Bio Inc., Shanghai, China) which used the sequence primers U1F (5'-CGTGCAGTCGGTATCGACCTCGG-3') and 2R (5'-CGATGCCGTTGGCGTCGATGTC-3').

\section{Phylogenetic analysis}

$16 \mathrm{~S}$ rRNA and $h s p 70$ gene sequences were compared to the GenBank nucleotide and protein databases using BLASTN and BLASTX (http://blast.ncbi.nlm.nih.gov/ Blast.cgi). Phylogenetic and molecular evolutionary analyses were conducted using MEGA 4.1 (Tamura et al. 2007). Briefly, for the construction of bootstrap test of $16 \mathrm{~S}$ rRNA and $h s p 70$ gene phylogenetic trees, the algorithm for the neighbour-joining (NJ) method (Saitou and Nei 1987) and Kimura 2-parameter model (Kimura 1980) were used. Percentage bootstrap values based on 1000 resampled datasets are shown.

\section{Nucleotide sequence accession numbers}

All the sequences used in this paper were deposited into GenBank under the accession numbers JF443561JF443576 and HQ607409-HQ607473, as indicated in Fig. 3.

\section{Results}

Design primers for the PCR amplification of $h s p 70$ genes PCR primers for the amplification of hsp70 (Dna K) genes were designed from two conserved regions of the amino acid sequences of the $70-\mathrm{kDa}$ heat shock protein from 20 genera in the actinomycetes (Fig. 1). Then, one primer pair was designed for amplifying approximately $1300 \mathrm{bp}$ of the $h s p 70$ gene fragment and the other primer pair was used to direct sequencing (Table 1). The primer pairs were aligned with the other gene sequences in the GenBank using BLAST (http://www.ncbi.nlm.nih.gov/ BLAST).

\section{PCR amplification of $h s p 70$ genes}

Primer optimization experiments were performed using a single primer pair ( $h s p 70-\mathrm{U} 7 \mathrm{~F}$ and $h s p 70-1326 \mathrm{R})$ to 
Acidothermus cellulolyticus Actinomadura spadix

Streptomyces coelicolor Frankia alni

Salinispora arenicola

Stackebrandtia nassauensis Actinosynnema mirum

Amycolatopsis mediterranei Saccharomonospora viridis Saccharopolyspora erythraea Catenulispora acidiphila Rhodococcus opacus Nocardia farcinica Corynebacterium jeikeium Cellulomonas flavigena Xylanimonas cellulosilytica Clavibacter michiganensis Micrococcus luteus Kineococcus radiotolerans Geodermatophilus obscurus Consensus

Acidothermus cellulolyticus Actinomadura spadix

Streptomyces coelicolor Frankia alni

Salinispora arenicola Stackebrandtia nassauensis Actinosynnema mirum Amycolatopsis mediterranei Saccharomonospora viridis Saccharopolyspora erythraea

Catenulispora acidiphila Rhodococcus opacus Nocardia farcinica Corynebacterium jeikeium Cellulomonas flavigena Xylanimonas cellulosilytica Clavibacter michiganensis Micrococcus luteus Kineococcus radiotolerans Geodermatophilus obscurus Consensus
(1) MARAVGIDLGTTNSVIAVLEGGEPTVIPNAEGSRTTPSVVAFAKNGEV

(1) MARAVGIDLGTTNSVVAILEGGEPTVIANAEGSRTTPSVVAFAKNGEV

(1) MARAVGIDLGTTNSVVSVLEGGEPTVITNAEGARTTPSVVAFAKNGEV

(1) MARAVGIDLGTTNSVVSVLEGGEPTVIANAEGSRTTPSVVAFAKNGEV

(1) MARAVGIDLGTTNSCVSVLEGGEPTVIANAEGSRTTPS IVAFARNGEV

(1) MARAVGIDLGTTNSCVSVLEGGEPTVITNAEGSRTTPS IVAFAKNGEV

(1) MARAVGIDLGTTNSVVAVLEGGEPTVIANSEGSRTTPS IVAFAKNGEV

(1) MARAVGIDLGTTNSVVAVLEGGEPTVIANSEGSRTTPS IVAFAKNGEV

(1) MARAVGIDLGTTNSVVAVLEGGEPTVIANSEGSRTTPS IVAFAKNGEV

(1) MARAVGIDLGTTNSVVSVLEGGESTVIANSEGSRTTPS IVAFAKNGEI

(1) MARAVGIDLGTTNSVVSVLEGGEPVVVANAEGSRTTPS IVAFAKNGEV

(1) MARAVGIDLGTTNSVVSVLEGGEPVVVANAEGSRTTPS IVAFAKNGEV

(1) MARAVGIDLGTTNSVVAVLEGGEPVVVANSEGSRTTPS IVAFAKNGEV

(1) MGRAVGIDLGTTNSVVSVLEGGEAKVIANSEGSRTTPS IVAFAKNGEV

(1) MARAVGIDLGTTNSVVATLEGGEPTVIANAEGARTTPSVVAFSKTGEV

(1) MARAVGIDLGTTNSVVTVLEGGEPTVIANAEGSRTTPSVVAFSKTGEV

(1) MARAVGIDLGTTNSVVSVLEGGEPTVIANAEGARTTPSVVAFTKDGEV

(1) MSRAVGIDLGTTNSVVAALEGGDPVVIANAEGARTTPSVVAFSKGGDV

(1) MARAVGIDLGTTNSVVSVLEGGEPTVIANAEGGRTTPSVVAFAKNGEV

(1) MARAVGIDLGTTNSVVTVLEGGEPTVIANSEGSRTTPSVVAFAKNGEV

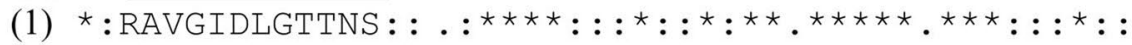

(425) KKLGMFELTGLPPAPRGVPQIEVTFDIDANGIVHVSAKDLATGKEQSM (424) KKLGTFQLTGLPPAPRGVPQIEVTFDIDANGIVNVGAKDLGTGKEQSM (423) KKLGMFELTGLPPAPRGVPQIEVAFDIDANGIMHVTAKDLGTGKEQKM (425) KKLGMFELTGLPPAPRGLPQIEVTFDIDANGIVHVSAKDLGTGKEQSM (424) KKLGTFELTGLPPAPRGMPQIEVTFDIDANGIVNVHAKDLGTGKEQKM (424) KKLGTFELTGLPPAPRGVPQVEVTEDIDANGIVNVSAKDVATGKAQSM (427) KKLGMFELTGLPPAPRGVPQIEVTFDIDANGIVHVSAKDMGTGKEQRM (426) KKLGMFELTGLPPAPRGVPQIEVTFDIDANGIVHVTAKDLGTNKEQSM (427) KKLGSEELTGIPPAPRGVPQIEVTFDIDANGIVHVTAKDLGTGKEQSI (426) KKLGMFELTGLPPAPRGVPQIEVSFDIDANGIVHVNAKDLGTGKEQSM (426) KLLGSFELADLPPAPRGVPQIEVTFDIDANG IVHVTAKDKGTGKENTI (426) KLLGSFELADLPPAPRGVPOIEVTFDIDANG IVHVTAKDKGTGKENTI (426) KLLGSEELTGIPPAPRGVPQIEVTFDIDANGIVHVTAKDKGTGKENTI (426) KLLGSEELAGIAPAPRGVPQIEVTFDIDANGIVSVSAKDKATGKENTI (430) KPLGTFELTGIAPAPRGMPQIEVTFDIDANGIVHVSAKDRGTGKEQSM (431) KPLGTFELTGIAPAPRGMPQIEVTFDIDANGIVHVSAKDRGTGREQSM (429) KNLGTFELTGIAPAPRGIPQVEVTFDIDANGIVHVSAKDKGTGKEQSM (429) KALGTFELTGIAPAPRGMPQIEVTFDIDANGIVHVSAKDKGTGTEQSM (430) KPLGTFELTGIAPAPRGVPQVEVTFDIDANGIVHVNAKDRGTGKEQSM (426) KKLGMFELTGLPPAPRGVPQIEVAFDIDANGIVHVHAKDLGTGKEQSM

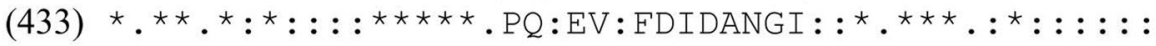

amplify the $h s p 70$ gene of Streptomyces coelicolor. The results showed that the sequences of the PCR product amplified from the primer pair was the same as the hsp70 genes retrieved from the Genbank database. Then, the primer pair described above was used to amplify the hsp70 genes in 16 Streptomyces strains. The PCR 
(See figure on previous page.)

Fig. 1 Sequence alignment of approximately 480N-terminal amino acids of 20 selected 70-kDa heat shock proteins from actinomycetes. Each protein sequences were deposited in GeneBank (Acidothermus. cellulolyticus: CP000481; Actinomadura spadix: AF451887; Streptomyces coelicolor: L46700; Frankia alni: CT573213; Salinispora arenicola: CP000850; Stackebrandtia. nassauensis: CP001778; Actinosynnema mirum: NC_013093;

Amycolatopsis mediterranei: CP002000; Saccharomonospora viridis: CP001683; Saccharopolyspora erythraea: AM420293; Catenulispora acidiphila: CP000431; Rhodococcus opacus: AP011115; Nocardia farcinica: AP006618; Corynebacterium jeikeium: CR931997; Cellulomonas flavigena: CP001964; Xylanimonas cellulosilytica: CP001821; Clavibacter michiganensis: AM849034; Micrococcus luteus: CP001628; Kineococcus radiotolerans: CP000750; Geodermatophilus obscurus: CP001867). "*" indicates where the residues are identical in all sequences in the alignment in that column. ":", "'!' indicates where conserved and semi-conserved substitutions are observed, respectively. Two conserved regions of the amino acid sequences enclosed in grey are used to design degenerated primers for the amplification of approximately 1300 bp hsp70 gene fragment

Table 1 Primers used for the PCR amplification of the hsp70 gene of Streptomyces strains

\begin{tabular}{|c|c|c|c|c|}
\hline Primer & Oligonucleotide sequence $^{a}$ & Length (bases) & Positions $^{\mathbf{b}}$ & Orientation \\
\hline hsp70-U7F & CGTGCAGTCGGTATCGACCTCGGBACVACBAACTC & 35 & $7-41$ & Sense \\
\hline hsp 70-1326R & CGATGCCGTTGGCGTCGATGTCGAASGHSACCTCGA & 36 & $1326-1363$ & Antisense \\
\hline $\mathrm{U} 1 \mathrm{~F}^{\mathrm{c}}$ & CGTGCAGTCGGTATCGACCTCGG & 23 & $7-29$ & Sense \\
\hline $2 R^{c}$ & CGATGCCGTTGGCGTCGATGTC & 22 & $1326-1347$ & Antisense \\
\hline
\end{tabular}

a IUB code for degenerated base positions: $B=G / C / T ; V=A / G / C ; S=C / G ; H=A / C / T$

b Positions correspond to the $h s p 70$ (DnaK) nucleotide sequence of S. coelicolor (GeneBank NO. L46700)

c Direct sequencing primers for hsp70-U7F/hsp70-1326R

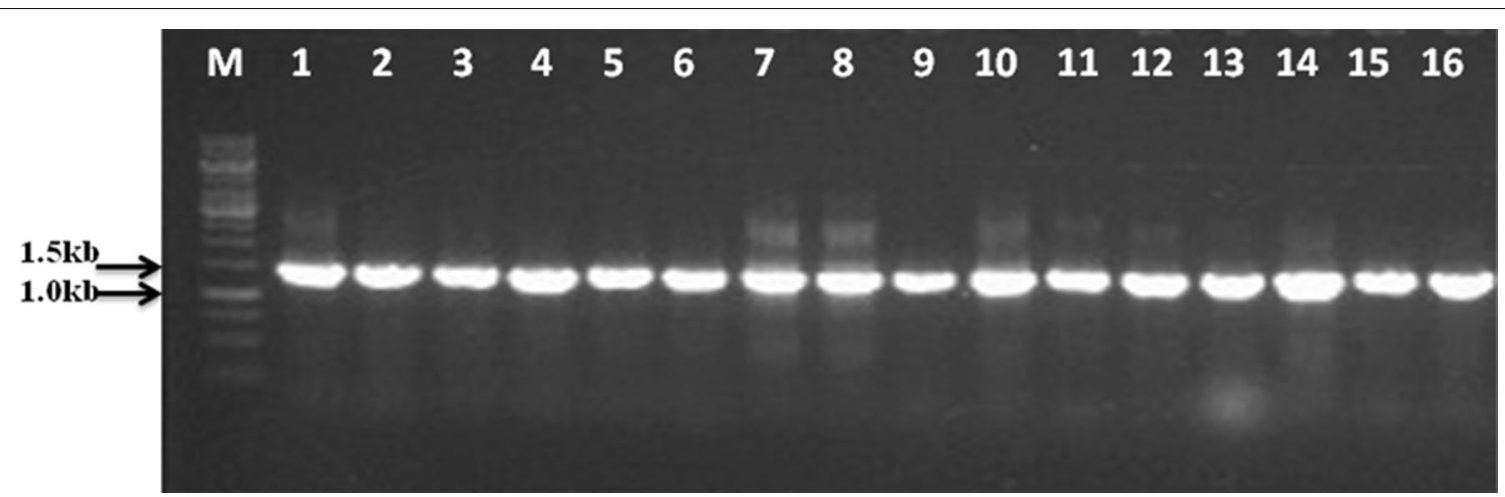

Fig. 2 Gel electrophoresis of PCR products amplified with degenerate primers (hsp70-U7F and hsp70-1326R). Lanes M, 1 kb DNA marker; lanes 1 to 16 , S. tendae strain 944, S. pluricolorescens strain 999, 1043 S. panayensis strain 1043, S. flavovariabilis strain 1067, S. macrosporeus strain 1076, S. drozdowiczii strain 1136, S. olivaceus strain 1137, S. chartreusis strain 1159, S. malaysiensis strain 1161, S. werraensis strain 1165, S. albogriseolus strain 1168, S. hawaiiensis strain 1183, S. castaneoglobisporus strain 1185, S. phaeofaciens strain 1187, S. acrimycini strain 1202

products with the expected size of approximately $1300 \mathrm{bp}$ corresponded to those predicted from known $h s p 70$ sequences (Fig. 2).

\section{Comparison of $h s p 70$ and 16S rRNA phylogenetic tree topologies}

When the phylogenetic trees constructed from the nucleotide sequences of $h s p 70$ and the $16 \mathrm{~S}$ rRNA gene from the same 16 Streptomyces reference strains were compared, analysis showed there were only slight differences between the phylogenetic structures for these
Streptomyces. Based on the bootstrap values and the level of the stability of the branches, the 16 strains of Streptomyces were divided into four stable subgroups (A, B, $\mathrm{C}$ and D) (Fig. 3a, b). According to the hsp70 phylogenetic tree, two strains, S. albogriseolus strain 1168 and S. acrimycini strain 1202, clustered closely in the A subgroup branch with a bootstrap value of $100 \%$, whereas $S$. acrimycini strain 1202 and S. macrosporeus strain 1076 clustered closely in the $16 \mathrm{~S}$ rRNA phylogenetic tree with a bootstrap value of $70 \%$. Therefore, subgroup A of $h s p 70$ phylogenetic tree showed higher stability than the $16 \mathrm{~S}$ rRNA phylogenetic tree. Furthermore, the strains in B, 
a

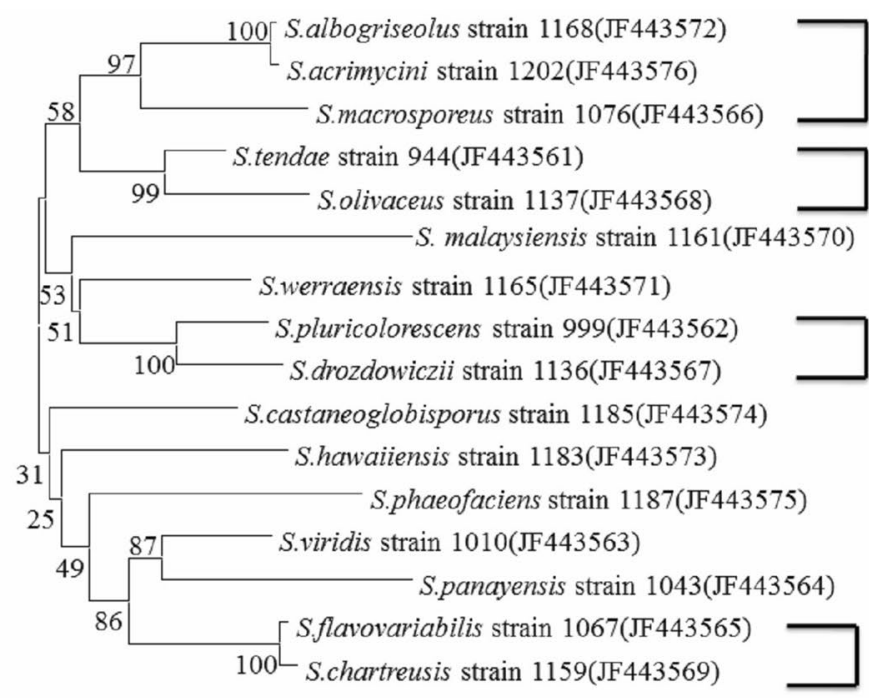

Cluster D
Cluster A

Cluster B

Cluster C
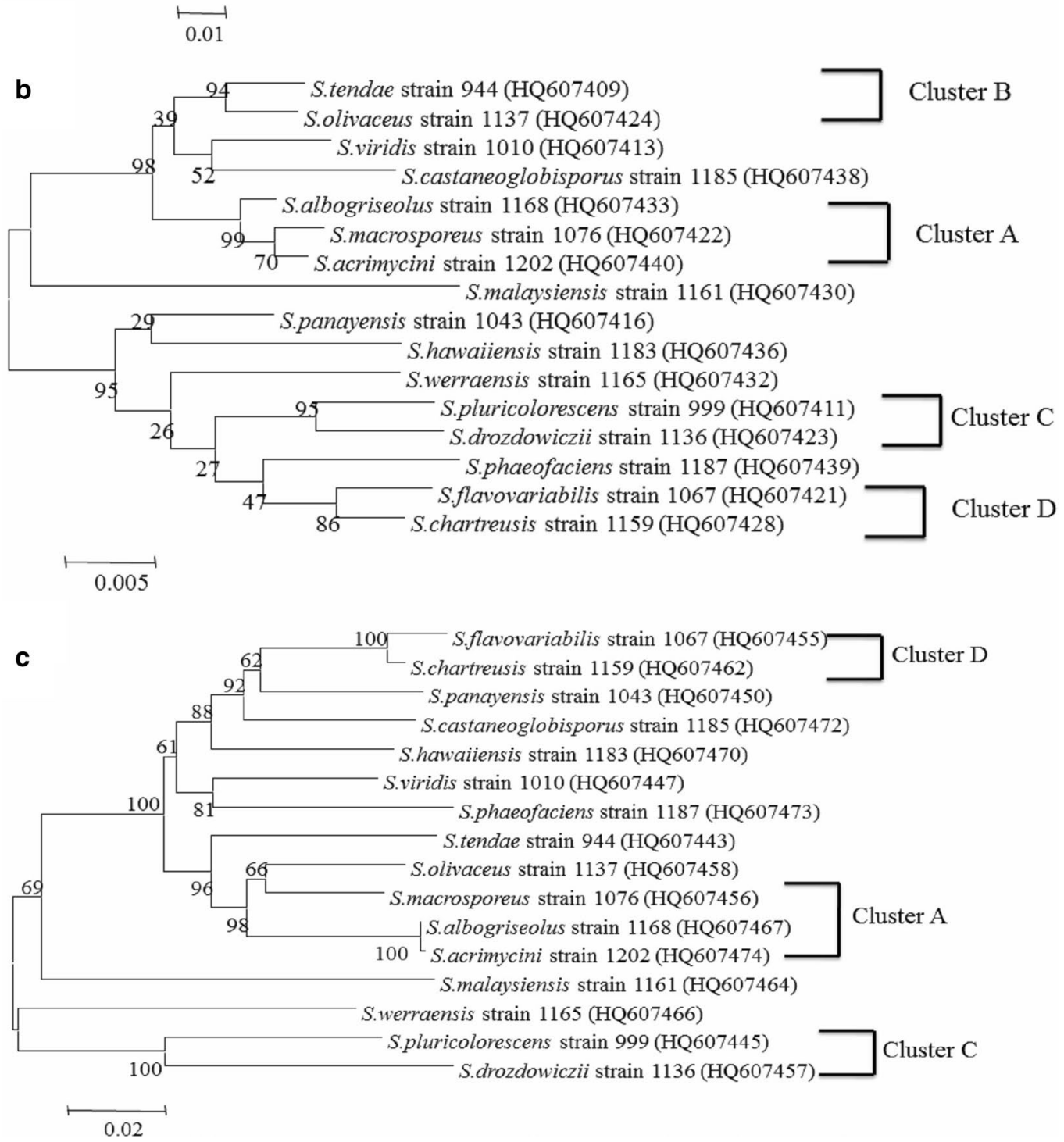

Fig. 3 Phylogenetic relationships based on the $h s p 70$ (a), 16S rRNA (b) and gyrB (c) gene sequences of 16 Streptomyces strains 
$\mathrm{C}$ and D subgroups also displayed higher stability for the hsp70 phylogenetic tree compared to the phylogenetic tree constructed from $16 \mathrm{~S}$ rRNA. In addition, two strains, S. viridis strain 1010 and S. panayensis strain 1043, were outside the four subgroups and clustered closely in $h s p 70$ phylogenetic tree with a bootstrap value of $87 \%$, and $S$. viridis strain 1010 clustered closely with $S$. castaneoglobisporus strain 1185; S. panayensis strain 1043 clustered closely with $S$. hawaiiensis strain 1183 with bootstrap values of $52 \%$ and $29 \%$, respectively. These results showed that the phylogenetic tree constructed from $h s p 70$ had a reasonable topology in comparison to the 16S rRNA phylogenetic tree.

\section{Comparison of $h s p 70$ and gyrB phylogenetic tree topologies}

Comparison between the $h s p 70$ and gyrB phylogenetic trees showed that there were some inconsistencies, leaving only 3 subgroups A, C and D (Fig. 3a, c). In both phylogenetic trees, these 3 subgroups were congruent and stable, but $h s p 70$ phylogenetic tree was even more reasonable. For example, in the $h s p 70$ and $g y r B$ phylogenetic trees, subgroup D clustered closely with $S$. panayensis strain 1043 with a bootstrap value $87 \%$ and $62 \%$, respectively; it seems that the branch in the $h s p 70$ phylogenetic tree had a reasonable topology. Also, in the hsp 70 phylogenetic tree, S. viridis strain 1010 and S. panayensis strain 1043 formed a more stable branch, but there were some differences from the phylogenetic tree based on gyrB. Among the phylogenetic trees (hsp70, 16S rRNA and $\operatorname{gyr} B$ ), it seems that the phylogenetic relationships of $S$. viridis strain 1010 and S. panayensis strain 1043 in the hsp70 phylogenetic tree was more reasonable.

\section{Discussion}

In modern taxonomy classifying bacteria, the $16 \mathrm{~S}$ rRNA and $\operatorname{gyr} B$ gene sequences have been considered to be simple and the most commonly used methods for the investigation of phylogenetic relationships (Dauga 2002; Fox et al. 1980; Fukushima et al. 2002; Hillis and Dixon 1991). Previous research has shown that the average substitution rate for $16 \mathrm{~S}$ rRNA was $1 \%$ per 50 million years which is slower than that of $\operatorname{gyr} B$ gene $(0.7 \%-0.8 \%$ per million years) (Ochman and Wilson 1987). Thus, the gyrB sequence analysis may better distinguish the phylogenetic relationships at the species level in some bacterial groups. However, this phylogenetic approach also has its limitations. Recently, rроB and $r e c A$ sequence analysis along with randomly amplified polymorphic fingerprinting could effectively identify Bacillus species with highly similar 16S rRNA gene sequences; these were hard to identify based on $16 \mathrm{~S}$ rDNA sequence analysis (Mohkam et al. 2016). Further, several mass spectrometry methods were used for the classification and identification of bacteria and other microorganisms (Sauer and Kliem 2010). For example, MALDI-TOF MS analysis was demonstrated to be a rapid method for bacteria identification from mining samples (Avanzi et al. 2017; Książczyk et al. 2016; Schröttner et al. 2016). Although many new analytical tools were recently used for the classification and identification of bacteria, there is still urgency for the discovery of new molecular markers.

The $60 \mathrm{kDa}$ heat-shock protein family hsp 65 gene has also been used successfully for species identification of cultured clinical isolates of the genus Mycobacterium (Rogall et al. 1990). The $h s p 70$ gene which is highly conserved between $16 \mathrm{~S}$ rRNA and gyrB sequences is distributed universally from bacteria to human beings (Hunt and Morimoto 1985). Consequently, it has the potential to be used as a phylogenetic marker for the investigation of phylogenetic relationships. However, using $h s p 70$ gene as a molecular marker for taxonomic identification is still rare to our knowledge.

Therefore, in this study, we attempted to develop novel PCR primers ( $h s p 70-\mathrm{UF}$ and $h s p 70-1326 \mathrm{R}$ ) for the investigation of the phylogenetic relationships of Streptomyces strains through amplification of the hsp 70 gene. Furthermore, the PCR products can be directly and rapidly sequenced by the sequence primers $\mathrm{U} 1 \mathrm{~F}$ and $2 \mathrm{R}$. Compared with the phylogenetic tree based on the $16 \mathrm{~S}$ rRNA gene and the $\operatorname{gyr} B$ gene, the $h s p 70$ phylogenetic tree has advantages for the investigation of the phylogenetic relationships of Streptomyces strains. Firstly, analysis based on the $h s p 70$ provided a resolving power higher than that of the 16S rRNA gene analysis in differentiating among species. Secondly, separation among closely related species such as S. panayensis strain 1043, S. viridis strain 1010 and S. phaeofaciens strain 1187, show that the $h s p 70$ phylogenetic tree provided convincing as well as reasonable phylogenetic relationships.

In conclusion, for the first time, this study develops novel PCR primers ( $h s p 70-\mathrm{U} 7 \mathrm{~F}$ and $h s p 70-1326 \mathrm{R}$ ) were used for the investigation of the phylogenetic relationships between 16 Streptomyces strains through amplification of $h s p 70$ gene. This gene may be a good alternative as a molecular marker for the phylogenetic analysis of Streptomyces strains. In the future, $h s p 70$ combined with $16 \mathrm{~S}$ rRNA and $\operatorname{gyr} B$ sequence method may be able to clarify molecular relationship of some controversial phylogenetic relationships of bacteria.

\section{Abbreviations}

hsp70: heat shock protein 70; gyrB: DNA gyrase, subunit B; PCR: polymerase chain reaction; DGGE: denaturing gradient gel electrophoresis; LH-PCR: length heterogeneity polymerase chain reaction; CPCR: comparative polymerase 
chain reaction; SSCP: single stranded conformation polymorphisms; ARDRA: amplified ribosomal DNA restriction analysis; AFLP: amplified fragment length polymorphism; RFLP: restriction fragment length polymorphism; FISH: fluorescence in situ hybridization; T-RFLP: terminal restriction fragment length polymorphisms.

\section{Authors' contributions}

WYL and YH conceived project, YH, FXS and WYL designed the study and wrote the paper. WYL and FXS performed the experiments, YH revised the English language. All authors reviewed the results. All authors read and approved the final manuscript.

\section{Author details}

1 Department of Pathogen Biology, School of Basic Medical Sciences, Tianjin Medical University, 22 Qi-Xiang-Tai Road, Tianjin 300070, China. ${ }^{2}$ Department of Physiology and Pathophysiology, School of Basic Medical Sciences, Tianjin Medical University, Tianjin 300070, China.

\section{Acknowledgements}

Not applicable.

\section{Competing interests}

The authors declare that they have no competing interests.

\section{Availability of data and materials}

All data analyzed in this article are included in the figures and tables. Any material used in this article is available for search purposes upon request.

\section{Consent for publication}

Not applicable.

Ethics approval and consent to participate

Not applicable.

\section{Funding}

This work was supported by the National Natural Science Foundation of China (81702905 and 81602512).

\section{Publisher's Note}

Springer Nature remains neutral with regard to jurisdictional claims in published maps and institutional affiliations.

Received: 27 June 2018 Accepted: 1 September 2018

Published online: 10 September 2018

\section{References}

Amann R, Ludwig W, Schleifer K (1995) Phylogenetic identification and in situ detection of individual microbial cells without cultivation. Microbiol Rev 59(1):143-169

Ash C, Farrow J, Dorsch M, Stackebrandt E, Collins M (1991) Comparative analysis of Bacillus anthracis, Bacillus cereus, and related species on the basis of reverse transcriptase sequencing of 16S rRNA. Int I Syst Bacteriol 41(3):343-346

Avanzi IR, Gracioso LH, Karolski B, Perpetuo EA (2017) Rapid bacteria identification from environmental mining samples using MALDI-TOF MS analysis. Environ Sci Pollut Res Int 24(4):3717-3726

Calcutt M (1994) Gene organization in the dnaA-gyrA region of the Streptomyces coelicolor chromosome. Gene 151(1-2):23-28

Christensen H, Nordentoft S, Olsen J (1998) Phylogenetic relationships of Salmonella based on rRNA sequences. Int I Syst Bacteriol 48(2):605-610

Das S, Dash HR, Mangwani N, Chakraborty J, Kumari S (2014) Understanding molecular identification and polyphasic taxonomic approaches for genetic relatedness and phylogenetic relationships of microorganisms. J Microbiol Methods 103:80-100

Dauga C (2002) Evolution of the gyrB gene and the molecular phylogeny of Enterobacteriaceae: a model molecule for molecular systematic studies. Int J Syst Evol Microbiol 52(2):531-547
Edwards U, Rogall T, Blocker H, Emde M, Bottger E (1989) Isolation and direct complete nucleotide determination of entire genes. Characterization of a gene coding for 165 ribosomal RNA. Nucleic Acids Res 17(19):7843-7853

Fox G, Stackebrandt E, Hespell R, Gibson J, Maniloff J, Dyer T, Wolfe R, Balch W, Tanner R, Magrum L (1980) The phylogeny of prokaryotes. Science 209(4455):457-463

Fukushima M, Kakinuma K, Kawaguchi R (2002) Phylogenetic analysis of Salmonella, Shigella, and Escherichia coli strains on the basis of the gyrB gene sequence. J Clin Microbiol 40(8):2779-2785

Giraffa G, Neviani E (2001) DNA-based, culture-independent strategies for evaluating microbial communities in food-associated ecosystems. Int J Food Microbiol 67(1-2):19-34

Hatano K, Nishii T, Kasai H (2003) Taxonomic reevaluation of whorl-forming Streptomyces (formerly Streptoverticillium) species by using phenotypes, DNA-DNA hybridization and sequences of gyrB, and proposal of Streptomyces luteireticuli (ex Katoh and Arai 1957) corrig., sp. nov., nom. rev. Int J Syst Evol Microbiol 53(Pt 5):1519-1529

Hedegaard J, Steffensen SA, Norskov-Lauritsen N, Mortensen KK, SperlingPetersen HU (1999) Identification of Enterobacteriaceae by partial sequencing of the gene encoding translation initiation factor 2. Int J Syst Bacteriol 49(Pt 4):1531-1538

Hillis D, Dixon M (1991) Ribosomal DNA: molecular evolution and phylogenetic inference. Q Rev Biol 66(4):411-453

Holmes D, Nevin K, Lovley D (2004) Comparison of 165 rRNA, nifD, recA, gyrB, rpoB and fus $A$ genes within the family Geobacteraceae fam. nov. Int J Syst Evol Microbiol 54(Pt 5):1591-1599

Hopwood DA, Bibb MJ, Chater KF, Kieser T, Bruton CJ, Kieser HM, Lydiate DJ, Smith CP, Ward JM (1985) Genetic manipulation of Streptomyces: a laboratory manual. The John Innes Foundation, Norwich

Hunt C, Morimoto R (1985) Conserved features of eukaryotic hsp70 genes revealed by comparison with the nucleotide sequence of human hsp70. Proc Natl Acad Sci USA 82(19):6455-6459

Kasai H, Tamura T, Harayama S (2000) Intrageneric relationships among Micromonospora species deduced from gyrB-based phylogeny and DNA relatedness. Int J Syst Evol Microbiol 50(1):127-134

Kimura M (1980) A simple method for estimating evolutionary rates of base substitutions through comparative studies of nucleotide sequences. J Mol Evol 16(2):111-120

Książczyk M, Kuczkowski M, Dudek B, Korzekwa K, Tobiasz A, KorzeniowskaKowal A, Paluch E, Wieliczko A, Bugla-Płoskońska G (2016) Application of routine diagnostic procedure, VITEK 2 compact, MALDI-TOF MS, and PCR assays in identification procedure of bacterial strain with ambiguous phenotype. Curr Microbiol 72(5):570-582

Küpfer M, Kuhnert P, Korczak B, Peduzzi R, Demarta A (2006) Genetic relationships of Aeromonas strains inferred from $16 \mathrm{~S}$ rRNA, gyrB and $r p o B$ gene sequences. Int J Syst Evol Microbiol 56(12):2743-2751

Lawrence J, Ochman H, Hartl D (1991) Molecular and evolutionary relationships among enteric bacteria. Microbiology 137(8):1911-1921

Lloyd A, Sharp P (1993) Evolution of the recA gene and the molecular phylogeny of bacteria. J Mol Evol 37(4):399-407

Mohkam M, Nezafat N, Berenjian A, Mobasher M, Ghasemi Y (2016) Identification of Bacillus probiotics isolated from soil rhizosphere using $16 \mathrm{~S}$ rRNA, recA, rpoB gene sequencing and RAPD-PCR. Probiotics Antimicrob Proteins 8(1):8-18

Mollet C, Drancourt M, Raoult D (1997) rpoB sequence analysis as a novel basis for bacterial identification. Mol Microbiol 26(5):1005-1011

Ochman H, Wilson A (1987) Evolution in bacteria: evidence for a universal substitution rate in cellular genomes. J Mol Evol 26(1):74-86

Rogall T, Flohr T, Bottger E (1990) Differentiation of Mycobacterium species by direct sequencing of amplified DNA. Microbiology 136(9):1915-1920

Saitou N, Nei M (1987) The neighbor-joining method: a new method for reconstructing phylogenetic trees. Mol Biol Evol 4(4):406-425

Sambrook J, Russell D (2001) Molecular cloning: a laboratory manual. CSHL press, Cold Spring Harbor

Sauer S, Kliem M (2010) Mass spectrometry tools for the classification and identification of bacteria. Nat Rev Microbiol 8(1):74-82

Schröttner P, Gunzer F, Schüppel J, Rudolph WW (2016) Identification of rare bacterial pathogens by $16 \mathrm{~S}$ rRNA gene sequencing and MALDI-TOF MS. J Vis Exp. https://doi.org/10.3791/53176 
Stackebrandt E, Goebel B (1994) Taxonomic note: a place for DNA-DNA reassociation and $16 \mathrm{~S}$ rRNA sequence analysis in the present species definition in bacteriology. Int J Syst Bacteriol 44(4):846-849

Tamura K, Dudley J, Nei M, Kumar S (2007) MEGA4: molecular evolutionary genetics analysis (MEGA) software version 4.0. Mol Biol Evol 24(8):1596-1599

Venkateswaran K, Dohmoto N, Harayama S (1998) Cloning and nucleotide sequence of the gyrB gene of Vibrio parahaemolyticus and its application in detection of this pathogen in shrimp. Appl Environ Microbiol 64(2):681-687

Woese C, Fox G, Zablen L, Uchida T, Bonen L, Pechman K, Lewis B, Stahl D (1975) Conservation of primary structure in 165 ribosomal RNA. Nature 254(5495):83-86

Woese C, Kandler O, Wheelis M (1990) Towards a natural system of organisms: proposal for the domains Archaea, Bacteria, and Eucarya. Proc Natl Acad Sci USA 87(12):4576-4579
Yamada S, Ohashi E, Agata N, Venkateswaran K (1999) Cloning and nucleotide sequence analysis of gyrB of Bacillus cereus, B. thuringiensis, B. mycoides, and $B$. anthracis and their application to the detection of $B$. cereus in rice. Appl Environ Microbiol 65(4):1483-1490

Yamamoto S, Harayama S (1996) Phylogenetic analysis of Acinetobacter strains based on the nucleotide sequences of gyrB genes and on the amino acid sequences of their products. Int J Syst Bacteriol 46(2):506-511

Yamamoto S, Harayama S (1998) Phylogenetic relationships of Pseudomonas putida strains deduced from the nucleotide sequences of gyr $\mathrm{B}, \mathrm{rpoD}$ and 165 rRNA genes. Int J Syst Bacteriol 48(3):813-819

Yamamoto S, Bouvet PJ, Harayama S (1999) Phylogenetic structures of the genus Acinetobacter based on gyrB sequences: comparison with the grouping by DNA-DNA hybridization. Int J Syst Bacteriol 49(1):87-95

\section{Submit your manuscript to a SpringerOpen ${ }^{\circ}$ journal and benefit from:}

- Convenient online submission

- Rigorous peer review

- Open access: articles freely available online

- High visibility within the field

- Retaining the copyright to your article

Submit your next manuscript at $\boldsymbol{\nabla}$ springeropen.com 